Abstracta Iranica Abstracta Iranica

Revue bibliographique pour le domaine irano-aryen

Volume 29 | 2008

Comptes rendus des publications de 2006

\title{
«Les lapidations en Iran ", in : Christine Ockrent, éd., Le livre noir de la condition des femmes. Paris, Éditions XO, 2006, pp. 131-148. (coll. «Points»)
}

\section{Christian Bromberger}

\section{(2) OpenEdition}

Journals

Édition électronique

URL : http://journals.openedition.org/abstractairanica/32002

DOI : 10.4000/abstractairanica.32002

ISSN : 1961-960X

Éditeur :

CNRS (UMR 7528 Mondes iraniens et indiens), Éditions de l'IFRI

Édition imprimée

Date de publication : 15 mai 2008

ISSN : 0240-8910

Référence électronique

Christian Bromberger, « «Les lapidations en Iran », in : Christine Ockrent, éd., Le livre noir de la condition des femmes. Paris, Éditions XO, 2006, pp. 131-148. (coll. «Points ») », Abstracta Iranica [En ligne],

Volume 29 | 2008, document 354, mis en ligne le 15 septembre 2008, consulté le 26 septembre 2020.

URL : http://journals.openedition.org/abstractairanica/32002 ; DOI : https://doi.org/10.4000/

abstractairanica.32002

Ce document a été généré automatiquement le 26 septembre 2020.

Tous droits réservés 


\section{« Les lapidations en Iran », in :} Christine Ockrent, éd., Le livre noir de la condition des femmes. Paris, Éditions XO, 2006, pp. 131-148. (coll. « Points »)

\section{Christian Bromberger}

1 La lapidation, prescrite non par le Coran, mais dans divers hadịt, figure dans le code pénal iranien ratifié par le parlement de la République islamique en 1982. Elle vise à châtier des individus reconnus coupables de rapports sexuels extra-conjugaux. Cette disposition nouvelle dans le droit iranien renforce "l'ordre patriarcal » et « la domination masculine ", conçue comme le reflet d'une " hiérarchie naturelle " " qui soumet la femme aux exigences sexuelles de son époux ». La menace d'accusation d'adultère est utilisée, note par ailleurs l'A., par les autorités judiciaires et les services de renseignements pour faire avouer aux prisonniers d'opinion leurs " crimes politiques ». Condamnée par la communauté internationale, la lapidation est aussi réprouvée par diverses autorités religieuses en Iran. L'isolement du pays renforcerait le pouvoir des factions les plus conservatrices et contribuerait au maintien de ce type de pratique ; son intégration dans la communauté internationale devrait entraîner la suppression de cette peine « en contradiction flagrante avec les principes des droits de l'homme ». 
INDEX

Thèmes : 12.1. Iran

\section{AUTEURS}

CHRISTIAN BROMBERGER

Université Aix-Marseille - IFRI 